\title{
HOLOCENE SEDIMENTARY RECORDS OF THE KATARRAKTES CAVE SYSTEM (NORTHERN GREECE): A STRATIGRAPHICAL AND ENVIRONMENTAL MAGNETISM APPROACH
}

\author{
RAZISKAVE HOLOCENSKE SEDIMENTACIJE V JAMI \\ KATARRAKTES (SEVERNA GRČIJA) S STRATIGRAFSKIMI IN \\ MAGNETNIMI METODAMI
}

\author{
Christos PENNOS ${ }^{1}$, Elina AIDONA², Sophia PECHLIVANIDOU ${ }^{1} \&$ Konstantinos VOUVALIDIS $^{1}$
}

\begin{abstract}
UDC 551.44:551.3.051(495)"628.64"

Christos Pennos, Elina Aidona, Sophia Pechlivanidou \& Konstantinos Vouvalidis: Holocene sedimentary records of the Katarraktes cave system (northern Greece): a stratigraphical and environmental magnetism approach

The Katarraktes cave system is located in northern Greece and is a complex of a rockshelter and a cave formed on the south river bank of Krousovitis River canyon (Serres, Macedonia region). The archaeological site area is well known as one of the most important archaeological sites in SE Europe since it hosts numerous archaeological findings dating back to the Early Bronze Age. Detailed stratigraphic analysis of three archaeological sections was performed in order to define the depositional conditions of the cave entrance facies sediments. Mineral magnetic properties were performed to enhance the paleoenvironmental interpretations and to detect sediment origins. Magnetic susceptibility $\left(\mathrm{k}_{\mathrm{lf}}\right)$ obtained in high and low frequency as well as remanence parameters, such as saturation isothermal remanent magnetization (SIRM) and S-ratio, were measured in samples collected from the archaeological sections. Results indicate a significant variability in the magnetic signal stored in the sedimentary record of Kataraktes cave system distinguishing between natural and anthropogenic sequences. The combination of the stratigraphic and magnetic results along with the archaeological data reveals that flood events of Krousovitis River and sediment accumulation from slackwater in the rockshelter area occurred around $3000 \mathrm{yr}$ BC and were possibly the key factor for the abandonment of the prehistoric settlement. Keywords: Katarraktes cave system, Greece, Mid-Holocene flood events, slackwater deposits, environmental magnetism.
\end{abstract}

\begin{abstract}
Izvleček
UDK 551.44:551.3.051(495)"628.64" Christos Pennos, Elina Aidona, Sophia Pechlivanidou \& Konstantinos Vouvalidi: Raziskave holocenske sedimentacije $v$ jami Katarraktes (Severna Grčija) s stratigrafskimi in magnetnimi metodami

Jamski sistem Katarraktes, ki ga sestavljata velik spodmol in podzemni rovi, leži na južnem obrežju kanjona reke Krousovitis (Serres, Makedonija, Severna Grčija). Kraj je eno najpomembnejših arheoloških najdišč v JV Evropi. Številne najdbe segajo v zgodnjo bronasto dobo. Na osnovi podrobne stratigrafske analize treh arheoloških profilov smo sklepali o sedimentacijskih pogojih na območju jamskega vhoda. $\mathrm{Z}$ raziskavami magnetnih lastnosti mineralov smo določali izvor sedimentov in značilnosti paleookolja. V vzorcih smo merili magnetno susceptibilnost pri visoki in nizki frekvenci ter parametre remanentnega magnetizma, kot sta izotermni remanentni magnetizem po nasičenju (SIRM) in S-količnik. $\mathrm{Na}$ osnovi variabilnosti magnetnega signala $\mathrm{v}$ sedimentih smo ločili obdobja naravnih in antropogenih plasti. Rezultati arheoloških, stratigrafskih in magnetnih raziskav kažejo, da so opustitev prazgodovinske naselbine povzročile poplave reke Krousovitis in sedimentacija iz poplavne vode približno 3000 let pred našim štetjem.

Ključne besede: jama Katarakktes, Grčija, holocenske poplave, poplavni sedimenti, geomagnetizem.
\end{abstract}

\footnotetext{
${ }^{1}$ Aristotle University of Thessaloniki, School of Geology, Department of Physical Geography

${ }^{2}$ Aristotle University of Thessaloniki, School of Geology, Department of Geophysics, e-mail: pennos@geo.auth.gr, sophiap@geo.auth.gr, aidona@geo.auth.gr,vouval@geo.auth.gr

Received/Prejeto: 19.08.2013
} 


\section{INTRODUCTION}

The paleoenvironmental significance of rockshelters and caves has long been recognized since these well protected environments act as important sediment traps that record past environmental conditions (Colcutt 1979; Karkanas 2001; Woodward \& Goldberg 2001). Sedimentary sequences preserved at the entrance of these cave systems usually contain materials formed directly at the site (autogenic), such as coarse debris derived from roof collapse, as well as materials introduced from off-site sources (allogenic), such as fine-grained sediments transported by wind and water and coarser particles transported by slope processes (Sroubek et al. 2001). Changes in the flux of the fine-grained allogenic sediments are often related to changes in the off-site environment and thus the study of the fine-grained component considered assessing local and regional environmental changes (Woodward et al. 2001). In addition, many cultural sequences and archaeological artifacts are well preserved in rockshelter and cave sediment records and can be effectively used for paleoenvironmental interpretation. Karstic sites were attractive locations for human activity since they provided protection. In the broader area of the Mediterranean numerous records concerning the prehistoric cultures of the region have been derived from archaeological remains excavated from these environments (e.g. Gamble 1986; Straus et al. 1996; Bailey et al.1999).

During the last decades, paleoenvironmental interpretation of sedimentary sequences preserved at rockshelters and caves around the Mediterranean region is being conducted by employing a variety of methodologies such as sedimentological, geochemical and micromorphological analysis (e.g. Karkanas 1999; Courty \& Vallverdu 2001; Straus et al. 2001; Woodward et al. 2001; Angelucci 2003; Turk \& Turk 2010), as well as paleontological analysis (Chatzopoulou et al. 2001; Toškan 2009). Also, long term and short term climate fluctuations have been documented from high-resolution isotopic speleothem records (e.g. Frisia et al. 1998; Bar-Matthews et al. 1999; Bar-Matthews \& Ayalon 2005).

Furthermore, mineral magnetic properties (e.g. magnetic susceptibility, remanence ratios such as ARM/ SIRM and S ratio) have been successfully used to recon- struct paleoenvironmental and paleoclimatic conditions in rockshelter and cave sites (e.g. Ellwood et al. 1996, 2004; Sroubek et al. 1998, 2001, 2007; Zupan et al. 2010). Environmental magnetism techniques allow a rapid, low cost and sensitive characterization of sediments and can be applied in a wide range of environments (Thompson \& Oldfield 1986). Magnetic properties of unconsolidated cave sediments serve as paleoclimatic proxies, since climate is the main factor controlling the magnetic signal of the source sediments, mainly as the result of pedogenesis. Pedogenic processes outside the cave produce abundant magnetic minerals such as maghemite, magnetite, hematite, and possibly greigite during periods when climate is relatively warm and wet. This increases the magnetic signature of sediments, which are protected from further pedogenesis and biological disturbance once redeposited inside caves (Ellwood et al. 2001).

In the present study we investigate the sedimentary record of three archaeological sections in the Katarraktes Cave system (Serres, Macedonia region, northern Greece), which is one of the most important archaeological sites in SE Europe. During the last eight years, the Ephorate of Paleoanthropology and Speleology of Northern Greece excavated numerous archaeological findings dating back to the Early Bronze Age. Previous studies have focused on the geoarchaeological setting of the karstic system (Pennos et al. 2008), while a paleoclimatic reconstruction of the site during human occupation has been performed, using isotopic fingerprints of carbonate sediments (Psomiadis et al. 2009). However, little attention has been given to the paleoenvironmental signal of the clastic sediments deposited at the entrance of the Katarraktes Cave system. In the present work we attempt an assessment of the paleoenvironmental conditions under which the deposition of the entrance facies sediments took place, coupling geomorphological, stratigraphical and environmental magnetism methods. The approach followed in this study enables a clear distinction between the natural and the anthropogenic signal stored in the sedimentary record of the Katarraktes Cave system. Moreover, a link between the detected environmental changes and the archaeological phases evidenced in the sedimentary record is provided.

\section{STUDY AREA}

\section{GEOLOGICAL SETTING}

The Katarraktes cave system is located at the southern banks of the Krousovitis River canyon, approximately
$2 \mathrm{~km}$ northwest of Sidirokastro city (northern Greece), at an altitude of $94 \mathrm{~m}$ above mean sea level (Fig. 1). The elevation of the Karstic site is approximately $10 \mathrm{~m}$ above the 


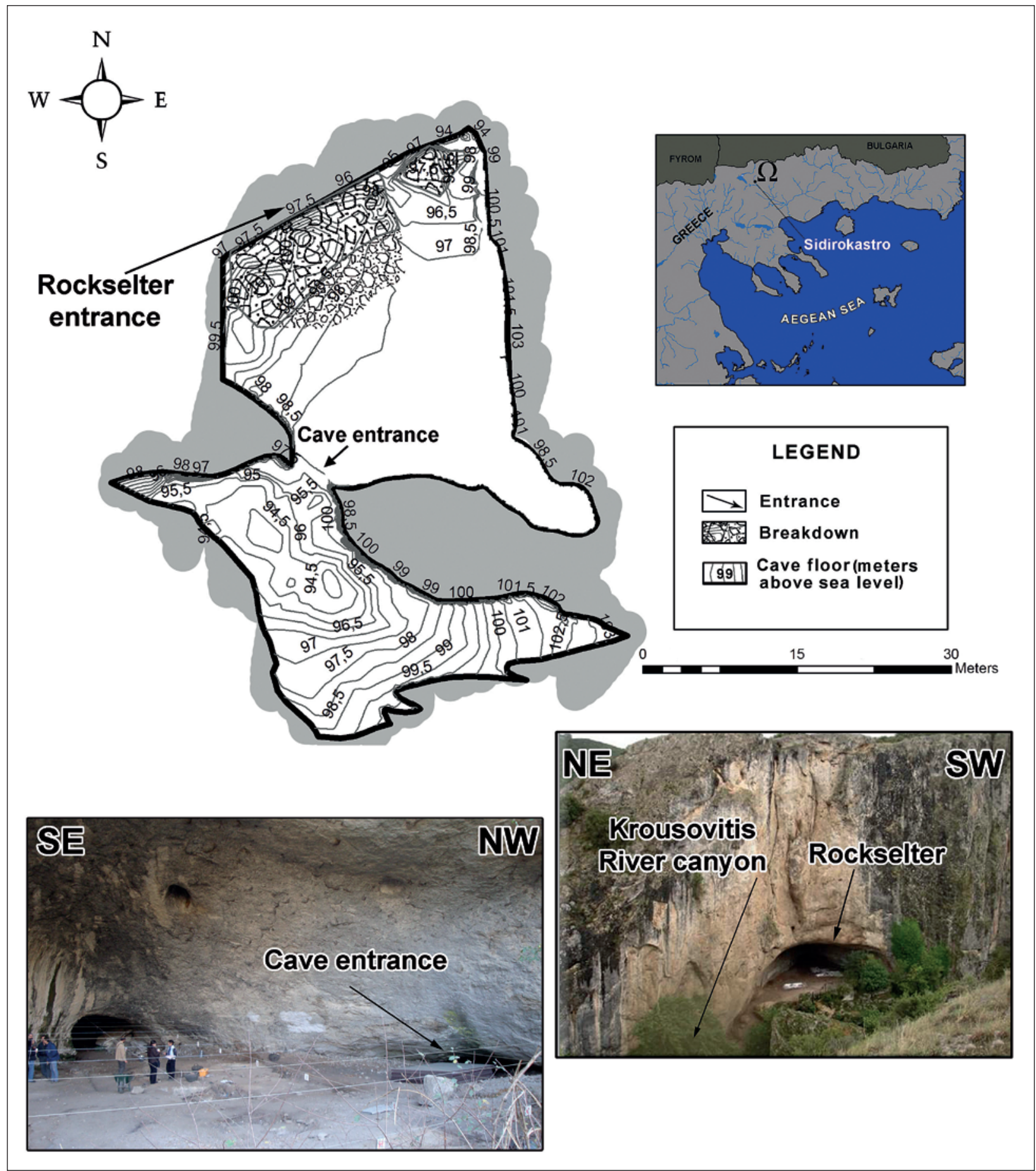

Fig. 1: Geographical setting of the Kararaktes cave system and ground plan of the site.

present river level. The total surface area of the Krousovitis River basin reaches almost $300 \mathrm{~km}^{2}$ and it is characterized by high geomorphological relief since it is part of the tectonic graben of Serres (Papafilippou-Pennou 2004). The broader area belongs to the Rhodope massif consisting of gneiss and marbles, while sediments of Neogene age, mainly conglomerates of granitic composition and silty sands, are superimposed at the bedrock. The Krousovitis River forms a canyon created due to intense tectonic uplift during the Early Neogene - Late Pliocene. Quaternary tectonic movements produced new, but less intense uplifts, which seem to have shaped the structure of the canyon during the Middle - Late Pleistocene (Psilovikos et al. 1981). Furthermore, quantitative geomor- 
phological analysis revealed that the tectonic activity is still intense and numerous caves at each side of the river bank likely indicative of older levels of the river flow are closely related to the tectonic regime of the area (Papafilippou-Pennou 2004).

\section{KATARRAKTES CAVE SYSTEM MORPHOLOGY AND SPELEOGENESIS}

Katarraktes cave system comprises a complex of a rockshelter and a cave (Fig. 1). The rockshelter has a vaulted shape and it is approximately $34 \mathrm{~m}$ wide and $22 \mathrm{~m}$ deep. The surface area of the site reaches $\sim 620 \mathrm{~m}^{2}$. The central part of the rockshelter is characterized by low relief (ground slopes are $\sim 0-7 \%$ ), while close to the entrance of the rockshelter the

relief is significant higher (ground slopes $>45 \%$ )

(Fig. 2, from Pennos et al. 2008). This morphology fa-

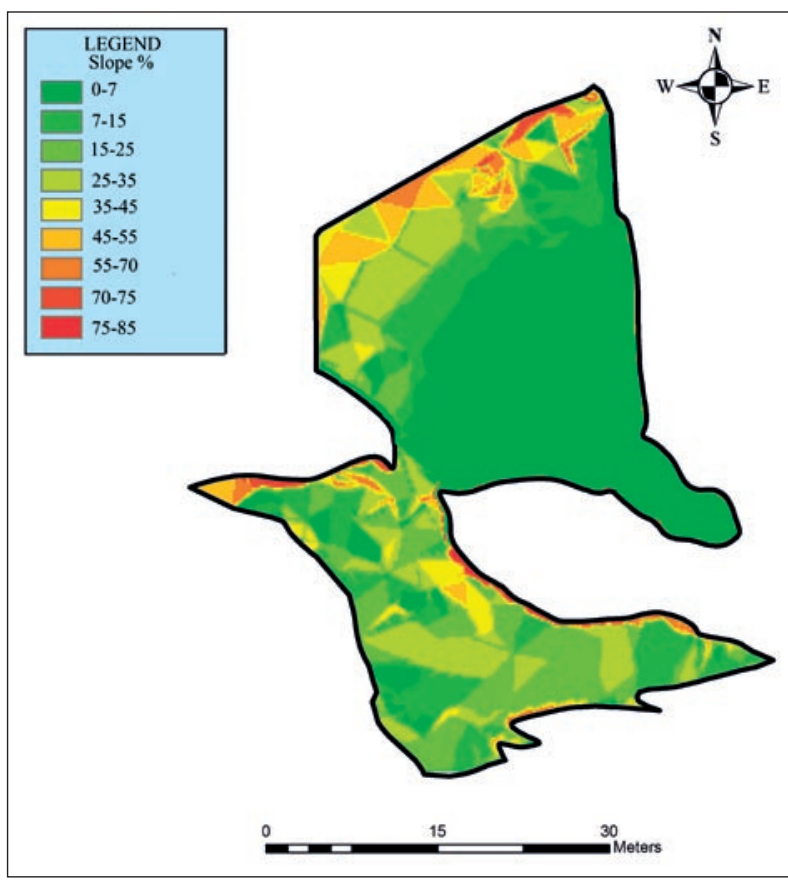

Fig. 2: Slope map of the Kataraktes cave system (from Pennos et al. 2008).

vors the deposition of fine sediments (fine sand, silt and clay) at the central part of the rockshelter and also the drainage of the cave during flood events of the Krousovitis River following the general slope of the floor to the north. Erosional surfaces observed in many archaeological sections, as well as deposition of fine sediments, granitic pebbles, shingles and breccias along with anthropogenic materials and charcoal deposits at the entrance of the cave system point to high-energy events connected with the fluvial action of the Krousonitis River. More- over, eroded calcite deposits overhanging portions of the cave entrance at an altitude of $1 \mathrm{~m}$ higher above the cave floor wall were also observed, indicating sediment outflow due to flood events and erosional phenomena of the palaeo-floor surface (Pennos et al. 2008).

Katarraktes cave has formed at the epiphreatic zone in limestone conglomerate while it passed at the vadose zone possible due to the tectonic uplift of the region during the Middle - Late Pleistocene. The cave is developed along a group of subvertical joints in a NW - SE direction that are the major speleogenetic factor, which control the orientation of cave passages. The whole cave system is closely linked to the karst hydrological network and thus it can be described as an active karst setting (Woodward \& Goldberg 2001). Seasonal water flows, dripping vadose waters and inwashing of fine sediments through conduits in the host bedrock are some of the key features of the Katarraktes cave system. Moreover, numerous carbonate deposits are present in the interior facies of the site, revealing a rather 'fresh' and rapid precipitation of carbonate material, indicated mainly by their porous texture (Psomiadis et al. 2009). At the entrance of the cave colluvial deposits are present, formed due to the regressive erosion and back stepping landslides of the canyon slopes.

\section{ARCHAEOLOGICAL DATA}

Archaeological research in the Katarraktes cave system started in 2004 and is continuing until 2013. Fig. 3 shows a plan view of the excavation site at the Katarraktes rockshelter. Excavations have revealed numerous archaeological finds, such as pottery and tools, dating back to the Early Bronze Age (Syros et al. 2008). Recent archaeological findings revealed two main prehistoric phases of occupation (named A and B phase), in contrast to previous archaeological studies where three phases of occupation had been proposed (Poulaki-Pantermali et al. 2006; Syros et al. 2008).

Both prehistoric phases of occupation (A and B phase) are mainly characterized by earthen floors interrupted by a thick clayey deposit, which is marked by the absence of any archaeological remains. The oldest archaeological phase (B phase) is detected more than half a meter below the surface and radiocarbon dating on charcoals revealed a range of ages between 3341 to 2915 cal yr BC (Syros \& Miteletsis 2012 in press). Moreover, ceramics date this phase approximately at the end of the $4^{\text {th }}$ millennium ( $3000 \mathrm{yr}$ BC) and suggest a close relation to the Sitagroi IV (Sherratt 1986) and Dikili Tash IIIA (Seferiades 1983) phases of eastern Macedonia. The youngest archaeological phase (A phase) includes mainly disturbed superficial layers. Charcoal deposits reveal an absolute age of 2880-2573 cal yr BC (Syros 

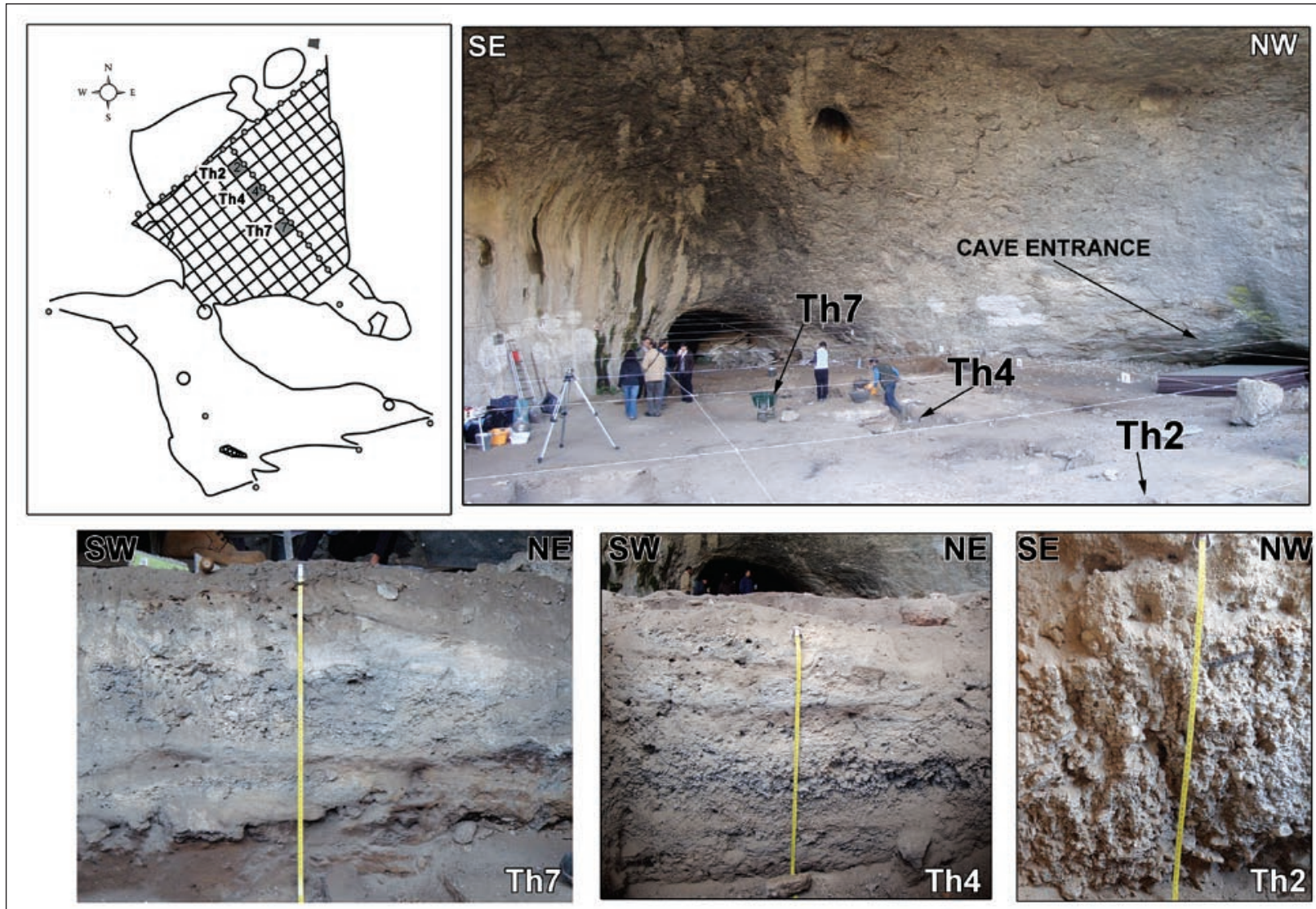

Fig. 3: Plan view of the excavation site at the Katarraktes rockshelter, with location and photographs of the studied archaeological sections, Th2, Th4 and Th7.

\& Miteletsis 2012 in press). This period is characterized by the phases Sitagroi V (Sherratt 1986) and Dikili Tash
IIIB (Seferiades 1983) for eastern Macedonia and Ezero B for Bulgaria.

\section{SAMPLING AND METHODOLOGY}

Three archaeological sections (Th2, Th4 and Th7) located at the central part of the Katarraktes rockshelter have been studied in detail (Figs. 3 and 4). Each archaeological trench is $2 \times 2 \mathrm{~m}$ while the profile depth extent varies from $50 \mathrm{~cm}$ to $63 \mathrm{~cm}$. The selected profiles are considered as the most representative among the remaining archaeological sections of the site, since they provide the best preserved stratigraphical and archaeological record. Profiles were cleared from loose debris and detailed logging of the stratigraphy was carried out before sampling. Bulk sampling was performed continuously throughout the three profiles and samples were packed in plastic boxes $\left(2 \times 2 \times 1.6 \mathrm{~cm}^{3}\right)$.

In the laboratory, low field volume magnetic susceptibility measurements $\left(\mathrm{k}_{\mathrm{lf}}\right)$ were obtained from each collected sample with a Bartington MS2 meter (resolution: $2 \times 10^{-6}$ SI on 0.1 range) and a Bartington MS2B dual frequency sensor at low $(0.465 \mathrm{kHz} \pm 1 \%)$ and high $(4.65 \mathrm{kHz} \pm 1 \%)$ frequency. Low-field susceptibility $\left(\mathrm{k}_{\mathrm{lf}}\right)$ is a concentration-depended magnetic parameter, indicating the concentration of the ferrimagnetic minerals (magnetite/maghemite) (Evans \& Heller 2003). The dual frequency enabled the estimation of the frequency depended magnetic susceptibility $\left(\mathrm{k}_{\mathrm{fd}}\right)$ which indicates the presence of ferrimagnetic grains close to the superparamagnetic stable single domain (SP) transition. Saturation isothermal remanent magnetization (SIRM) was imposed by applying a maximum field of $1 \mathrm{~T}$ DC-field in a Pulse Magnetizer, while a reverse field $(-300 \mathrm{mT})$ was applied to evaluate the $S_{-300}\left(\operatorname{IRM}_{-300 \mathrm{mT}} / \mathrm{SIRM}_{1 \mathrm{~T}}\right) \mathrm{ra}-$ 
tio (King \& Channell 1991). $S_{-300}$ ratio is a widely used proxy of the magnetic mineralogy, with values close to unity suggesting that magnetite controls the magnetic signal (Stober \& Thompson 1979). Measurements of both SIRM $_{1 \mathrm{~T}}$ and IRM $_{-300 \mathrm{mT}}$, were performed using a Molspin magnetometer.

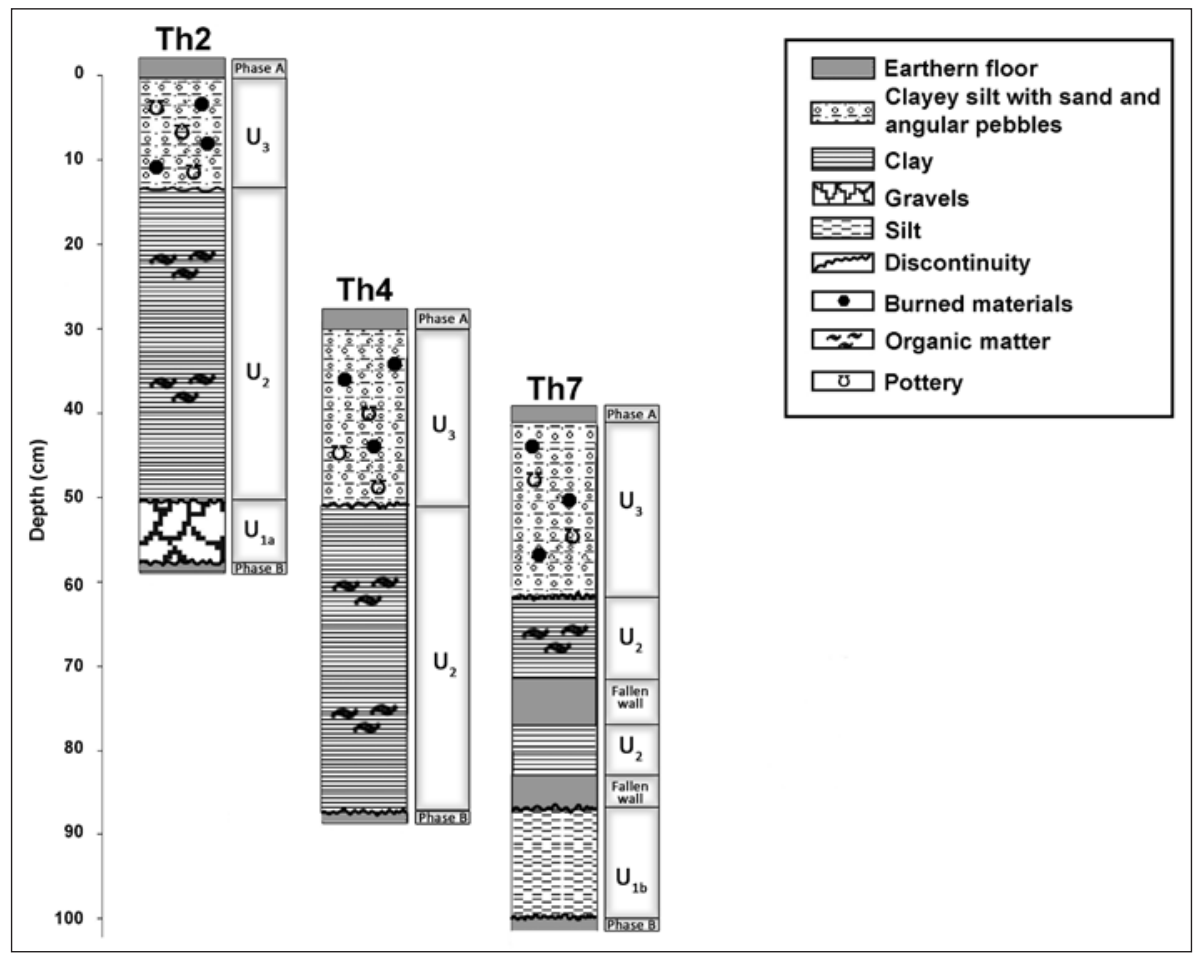

Fig. 4: Stratigraphic columns of the archaeological sections Th2, Th4 and Th7.

\section{RESULTS}

\section{DETAILED STRATIGRAPHY}

Archaeological sections Th2, Th4 and Th7, show a rather similar stratigraphic architecture; sequences of clayey sediments alternating with silty and sandy layers with scattered gravels are found between the two clayey archaeological floors, corresponding to the archaeological phases A кaı B. The detailed stratigraphic study revealed three successive depositional units, which can be described as follows (Fig. 4):

The first unit $\left(\mathrm{U}_{1}\right)$ is found at the deepest parts of Th2 and Th7 profiles. It overlies an archaeological floor composed of packed clay, which corresponds to the archaeological phase $\mathrm{B}$. $\mathrm{U}_{1}$ is subdivided into two distinct depositional units, $\mathrm{U}_{1 \mathrm{a}}$ and $\mathrm{U}_{1 \mathrm{~b}} . \mathrm{U}_{1 \mathrm{a}}$ is found in Th2 profile at $\sim 50 \mathrm{~cm}$ depth and has a maximum thickness of $\sim 7 \mathrm{~cm}$. It consists of coarse material, mainly poorly sorted gravels and angular pebbles. $U_{1 b}$ is found in Th7 profile at $87 \mathrm{~cm}$ depth and is composed of fine grained sediments (fine sand, silt and clay), with a maximum thickness of $\sim 15 \mathrm{~cm}$.
The second unit $\left(\mathrm{U}_{2}\right)$ overlies uncomfortably $\mathrm{U}_{1}$ in Th2 and Th7 profiles, while it is found directly above the lowest archaeological floor (archaeological phase B) in Th4 profile. The sediment texture of this unit is mainly composed of light grey silty clay. Mineralogical analysis (XRD) of representative samples has shown that the main phase of the studied material is calcite. Quartz and feldspars were contained in smaller quantities, while dolomite, micas and clays were found in minor amounts. Organic residuals, mainly plant remains, are also scattered throughout the sediment. The thickness of this unit varies from $37 \mathrm{~cm}$ in Th2 profile to $27 \mathrm{~cm}$ in Th7 profile. In addition, two clayey insertions that have been recognized as parts of a fallen wall (Syros \& Miteletsis 2012 in press) are noticeable in Th7 profile, between the depth ranges $72-78 \mathrm{~cm}$ and $83-87 \mathrm{~cm}$.

The third unit $\left(\mathrm{U}_{3}\right)$ is found at the upper parts of Th2, Th4 and Th7 profiles, overlying uncomfortably $\mathrm{U}_{2}$. It has a maximum thickness of approximately $20 \mathrm{~cm}$ and includes poorly sorted sandy silt and silty clay with an- 
gular pebbles. Pottery, burned seeds and cereals are noticeable, pointing to anthropogenic origins for these sediments. At the upper part of this unit an archaeological floor consisting of packed clay is present, corresponding to the youngest archaeological phase A.

\section{MAGNETIC PROPERTIES}

The variation with depth of all the magnetic parameters examined for the studied archaeological sections Th2, Th4 and Th7 are shown in Fig. 5. In Th2 profile (Fig. 5A) magnetic susceptibility $\left(\mathrm{k}_{1 \mathrm{f}}\right)$ shows a generally increasing trend from the lowest part of the section $(50 \mathrm{~cm}$ depth) to its upper part. Mean $\mathrm{k}_{\mathrm{lf}}$ values are approximately $80 \times 10^{-5} \mathrm{SI}$ across $\mathrm{U}_{2}$ below $12.5 \mathrm{~cm}$ depth, while they are significantly higher at the upper part of the profile across $U_{3}$, reaching mean values of $\sim 223 \times 10^{-5}$ SI. The SIRM $\log$ follows a similar trend as the magnetic susceptibility; lower SIRM values (mean $\sim 3 \mathrm{~A} / \mathrm{m}$ ) are found between $50 \mathrm{~cm}$ and $12.5 \mathrm{~cm}$ depth $\left(\mathrm{U}_{2}\right)$, while higher SIRM values (mean $\sim 6.5 \mathrm{~A} / \mathrm{m}$ ) characterize the upper part $\left(\mathrm{U}_{3}\right)$ of the Th2 profile. $S_{-300}$ depict a slightly opposite trend with values $>0.85$ for $U_{2}$ which are decreasing upwards $(<0.85)$ across $U_{3}$. Moreover, percentage of frequency dependence susceptibility $\left(\mathrm{k}_{\mathrm{fd}} \%\right)$ yields relatively low values (mean $\sim 3 \%$ ) for both units $\mathrm{U}_{2}$ and $\mathrm{U}_{3}$.

Th4 profile shows a similar magnetic signature with Th2, with an increasing trend towards the surface for $\mathrm{k}_{\mathrm{If}}$ and SIRM parameters that also distinguish between $\mathrm{U}_{2}$ and $\mathrm{U}_{3}$ (Fig. 5B). Lower $\mathrm{k}_{\mathrm{lf}}$ and SIRM values are observed at the interval between $90 \mathrm{~cm}$ and $50 \mathrm{~cm}$ across
$\mathrm{U}_{2}$ (mean $\sim 70 \times 10^{-5} \mathrm{SI}$ and $\sim 3.6 \mathrm{~A} / \mathrm{m}$, for $\mathrm{k}_{\mathrm{If}}$ and SIRM, respectively), while higher $\mathrm{k}_{\mathrm{If}}$ and SIRM values (mean $140 \times 10^{-5} \mathrm{SI}$ and $\sim 6.5 \mathrm{~A} / \mathrm{m}$, for $\mathrm{k}_{\mathrm{If}}$ and SIRM, respectively) are found at the interval between $50 \mathrm{~cm}$ and $30 \mathrm{~cm}$, across $\mathrm{U}_{3}$. Moreover, the $\mathrm{k}_{\mathrm{fd}} \%$ pattern mimics the variation of magnetic susceptibility and SIRM with depth and shows a significant increase above $6 \%$ between $60 \mathrm{~cm}$ and $50 \mathrm{~cm}$ depth. $\mathrm{S}_{-300}$ is almost constant ranging from 0.9 to 0.98 with an exception occurs at $50 \mathrm{~cm}$ showing a lower value of 0.84 that indicates possible presence of high coercivity minerals (e.g. hematite).

For the Th7 profile the variation of the magnetic parameters is more complex (Fig. 5C). At the lower part of the Th7 profile across $U_{1 b}$ (below $90 \mathrm{~cm}$ depth) $k_{\text {If }}$ depicts high values (mean $\sim 200 \times 10^{-5} \mathrm{SI}$ ). Going upwards to $\mathrm{U}_{2}, \mathrm{k}_{\mathrm{lf}}$ values are significant lower (mean $\sim 93 \times 10^{-5} \mathrm{SI}$ ) and are interrupted by two observed peaks at the depths of $88 \mathrm{~cm}$ and $75 \mathrm{~cm}\left(\mathrm{k}_{\mathrm{lf}}\right.$ values are $275 \times 10^{-5} \mathrm{SI}$ and $\sim 240 \times 10^{-5}$ SI, respectively). These layers correspond to the two fallen walls, also observed in the archaeological record. $\mathrm{k}_{\mathrm{lf}}$ values exhibit again relatively high values (mean $\sim 200 \times 10^{-5} \mathrm{SI}$ ) for the upper part of the section above $60 \mathrm{~cm}$ depth, within $\mathrm{U}_{3}$. SIRM show a similar trend as the magnetic susceptibility emphasizing in the two peaks of the fallen walls. Furthermore, $S_{-300}$ ratio is rather constant along the profile with no values lower than 0.83 . Finally, the $\mathrm{k}_{\mathrm{fd}} \%$ shows increased values of $6 \%$ up to $80 \mathrm{~cm}$ depth followed by lower values in the range of about $4 \%$ until the end of the profile.

\section{DISCUSSION}

Stratigraphic analysis of the archaeological sections Th2, Th4 and Th7, allowed the subdivision of the Katarraktes sedimentary sequence into three depositional units; $U_{1}$, $\mathrm{U}_{2}$ and $\mathrm{U}_{3}$, also supported by observed mineral magnetic properties. These units were deposited under different palaeoenvironmental conditions, showing both natural and anthropogenic origins. $U_{1}$, consists of natural deposits found at the lower parts of the archaeological sections $\mathrm{Th} 2$ and $\mathrm{Th} 7$ and corresponds to the sedimentation phase that took place after the archaeological phase B, dated back at 3341-2915 cal yr BC. Magnetic analysis of $\mathrm{U}_{1}$ was performed only in section Th7, since in section Th2 the observed subunit $U_{1 \mathrm{a}}$ consists of coarse grained sediments (gravels and pebbles), making it impossible to sample. These coarse deposits are most likely part of the debris cone that was formed at the entrance of the rockshelter, as a result of the wall regression of the can- yon. Nevertheless, mineral magnetic analysis of subunit $\mathrm{U}_{1 \mathrm{~b}}$ indicates a relatively high concentration of magnetic minerals, revealed by high $\mathrm{k}_{\mathrm{lf}}$ and SIRM values. A possible explanation for the observed magnetic signals within subunit $U_{1 b}$ could be the influence from the underlying archaeological phase B and a probable mixing with magnetically enhanced materials. Archaeological soils are generally characterized by large amounts of magnetic minerals, depicting relatively high magnetic susceptibility values (Thompson \& Oldfield 1986; Evans \& Heller 2003; Dalan 2008). Fluvial processes could have caused the mixing with the underlying archaeological remains; the unconformity found at the lowest part of subunit $U_{1 b}$ points to a period of erosion, reinforcing the suggestion of fluvial influence.

Similar magnetic signals are observed for the $U_{3}$, which is clearly identified at the upper parts of the pro- 


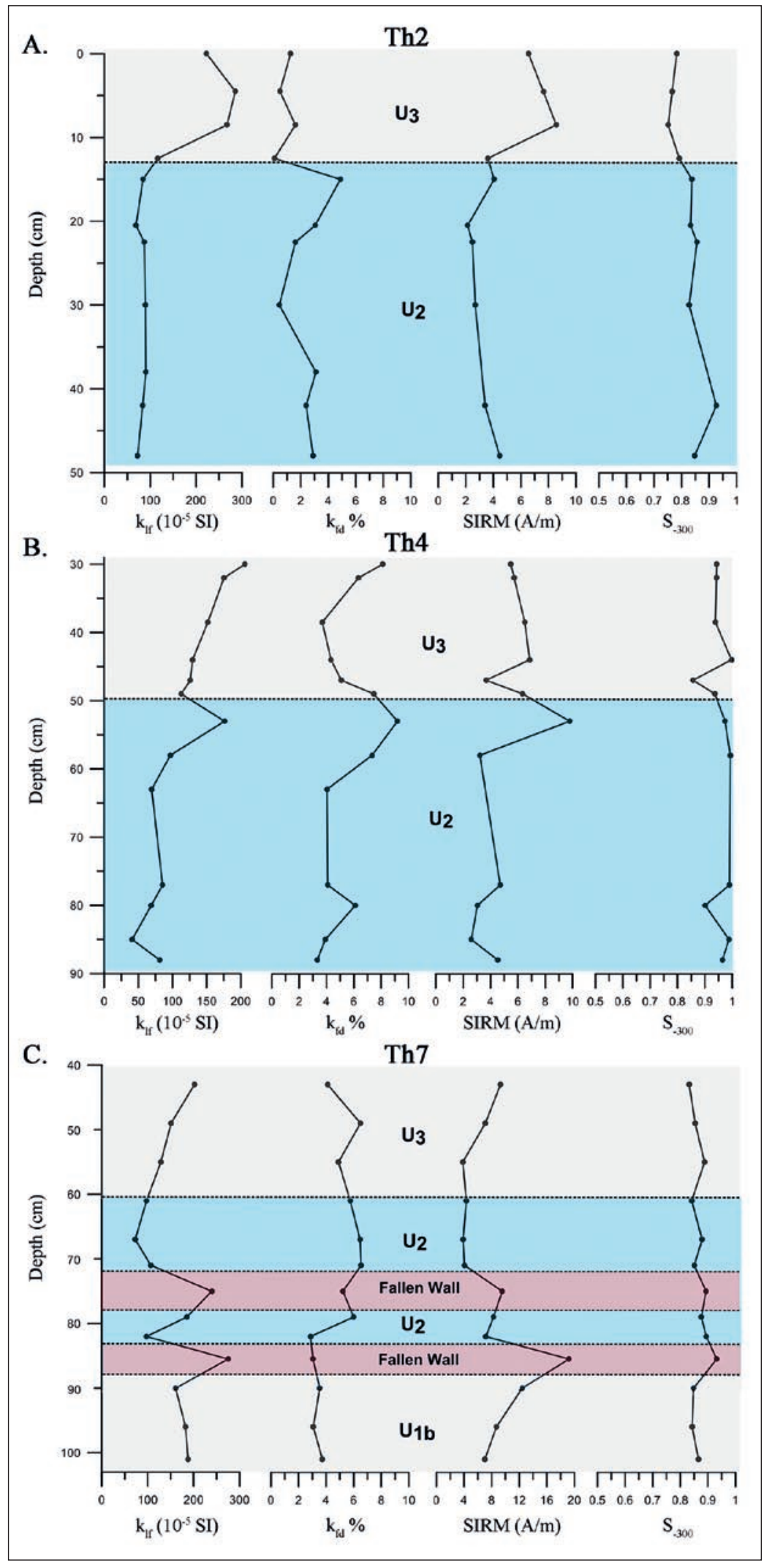

Fig. 5: Variation of mineral magnetic properties, klf $\left(10^{-5} \mathrm{SI}\right), \mathrm{kfd} \%$, SIRM and $\mathrm{S}_{-300}$, along the three profiles (For details see in the text). files Th2, Th4 and Th7, below the earthen floor that corresponds to the youngest archaeological phase A $(2880-2573 \mathrm{cal}$ yr BC). Pottery, burnt seeds and other archeological remains reveal human interference and also account for the high $\mathrm{k}_{\mathrm{lf}}$ and SIRM values.

In contrast, $\mathrm{U}_{2}$ shows a clearly different magnetic behavior compared to the other two units. Magnetic susceptibility $\left(\mathrm{k}_{\mathrm{f}}\right)$ and SIRM yield lower values, indicating a low concentration of magnetic minerals. This could be due to dilution of minerogenic matter caused by increased organic sedimentation, since a considerable amount of organic matter is observed throughout $\mathrm{U}_{2}$. Furthermore, the percentage of $k_{\mathrm{fd}} \%$ shows a slightly increasing upwards trend through this unit, reaching values close to $6 \%$ that point to the possible presence of ultra-fine superparamagnetic (SP) magnetite grains (Dearing et al. 1996). Weymouth (2003) reported similar peak values of $\mathrm{k}_{\mathrm{fd}} \%$ in archaeological trenches and concluded that these are indicative of a soil development period, probably related to a period of stability before the erosive processes from the historic cultivation take place.

The magnetic mineralogy referred by $\mathrm{S}_{-300}$ ratio is rather uniform for units $1-3$ in all studied profiles. This is indicative of the dominance of magnetite grains as the main magnetic carriers for the sedimentary record of Katarraktes cave system, but further magnetic analysis is needed in order to assess the magnetic mineralogy of the site.

The above discussion concerning the behavior of the magnetic parameters, especially the magnetic susceptibility and the SIRM (which show the biggest variations) can be summarized in Fig. 6. A unified plot composing the results of the magnetic susceptibility and SIRM from the 3 profiles is presented in order to better distinguish the different units by means of magnetic properties. The position of the samples has been normalized within each unit using a linear correlation and all results have been plotted using different colors for each 
profile respectively. The line represents the moving average of the obtained results excluding the points which corresponds to the fallen walls. This synthetic plot confirms the presence of high values in anthropogenic (or mixed) layers $U_{3}$ and $U_{1}$ respectively, while in $U_{2}$ values of $\mathrm{k}_{\mathrm{lf}}$ and SIRM are systematic lower.

The stratigraphic and magnetic analysis of the archaeological sections at the Katarraktes cave system provides evidence that can be employed for the paleoenvironmental reconstruction of the site during the Middle - Late Holocene. The clayey sediments comprising $U_{1 b}$ and $\mathrm{U}_{2}$ form naturally deposits accumulated uncomfortably above the earthen floor of Middle Holocene age (phase B), while the underlying anthropogenic strata $\left(\mathrm{U}_{3}\right)$. The stratigraphic position of these units following the morphology of the rockshelter's floor, as well as the erosional surfaces observed in the three profiles above the oldest archaeological floor (Fig. 4), suggest the occurrence of high-energy events (e.g. floods of Krousovitis River) that must have interrupted the human occupation in the site. Moreover, the two parts of a fallen earthen wall in Th7 profile recorded from archaeological data, as well as from the stratigraphic and magnetic analysis, further support the suggestion of the presence of catastrophic events in the site area. According to the archaeological datings these flood events should have been taken place at the time span between $\sim 3120 \mathrm{cal}$ yr BC and $\sim 2720$ cal yr BC. Evidence of possible flood events of Krousovitis River has also been reported from previous studies at the site (Pennos et al. 2008; Psomiadis et al. 2009).
The detailed analysis of the Katarraktes sequence reveals that $\mathrm{U}_{1 \mathrm{~b}}$ consists of sediments deposited by fluvial processes. However this unit is only evident in Th7 profile since it is located at the deeper parts of the Katarraktes rockshelter compared to the other two profiles (Fig. 4). $\mathrm{U}_{2}$, is apparent in all archaeological sections and is also composed of fluvial deposited sediments. The mineralogical analysis reinforces the above observation since the composition of the sediments corresponds to natural deposits. The presence of fine grained sediments and organic material across $\mathrm{U}_{2}$, along with the small concentration of magnetic minerals demonstrate deposition under low energy conditions, most likely from slackwater during the floods of Krousovitis River. Studies from rockshelters sites around the Mediterranean have shown that these environments may form important slackwater sedimentation zones (Woodward \& Goldberg 2001 and references therein). However, only few slackwater deposits in rockshelters and caves have been reported in Greece mainly from Voidomatis River basin (Lewin et al. 1991; Hamlin 2000; Woodward et al. 2001).

The detected flood events of the Krousovitis River must have acted as the key factor for the abandonment of the settlement in the study area between $\sim 3120 \mathrm{cal} \mathrm{yr}$ $\mathrm{BC}$ and $\sim 2720 \mathrm{cal}$ yr BC. The timeframe of these events is in good agreement with paleoclimatic studies for the Katarraktes cave system, suggesting wet climatic conditions during this period (Psomiadis et al. 2009).

\section{CONCLUSIONS}

Stratigraphic analysis of three archaeological sections at the Katarraktes cave system combined with mineral magnetic analysis of sediments and archaeological data revealed the paleoenvironmental conditions under which the cave entrance phases accumulated. Both natural and anthropogenic sequences were observed, organized in three successive depositional units $\left(\mathrm{U}_{1}-\mathrm{U}_{3}\right)$.

Fine-grained sediments lying uncomfortably above the earthen floor of Middle Holocene age and following the rockshelter's floor in combination with the absence of archaeological findings, suggests deposition by fluvial processes and in particularly from slackwater during the flood events of Krousovitis River. These slackwater deposits show rather small concentration of magnetic minerals reflected by low values of $\mathrm{k}_{\mathrm{If}}$ and SIRM that caused by increased organic sedimentation. Furthermore, the presence of ultra-fine superparamagnetic (SP) magnetite grains reflected by increased $\mathrm{k}_{\mathrm{fd}} \%$ values, also points to deposition under low energy conditions.

The flooding events of Krousovitis River took place between 3120-2720 cal yr BC and were possible the key factor for the abandonment of the settlement in the study area. The combined analysis followed in this study reveals the presence of two parts of a fallen wall that interrupt the naturally deposited sediments and point to a catastrophic event. Furthermore, additional magnetic measurements in the other archaeological section available in the site could provide more information in order to further constrain the detailed palaeoenvironmental signals of the cave entrance deposits of the site area. 

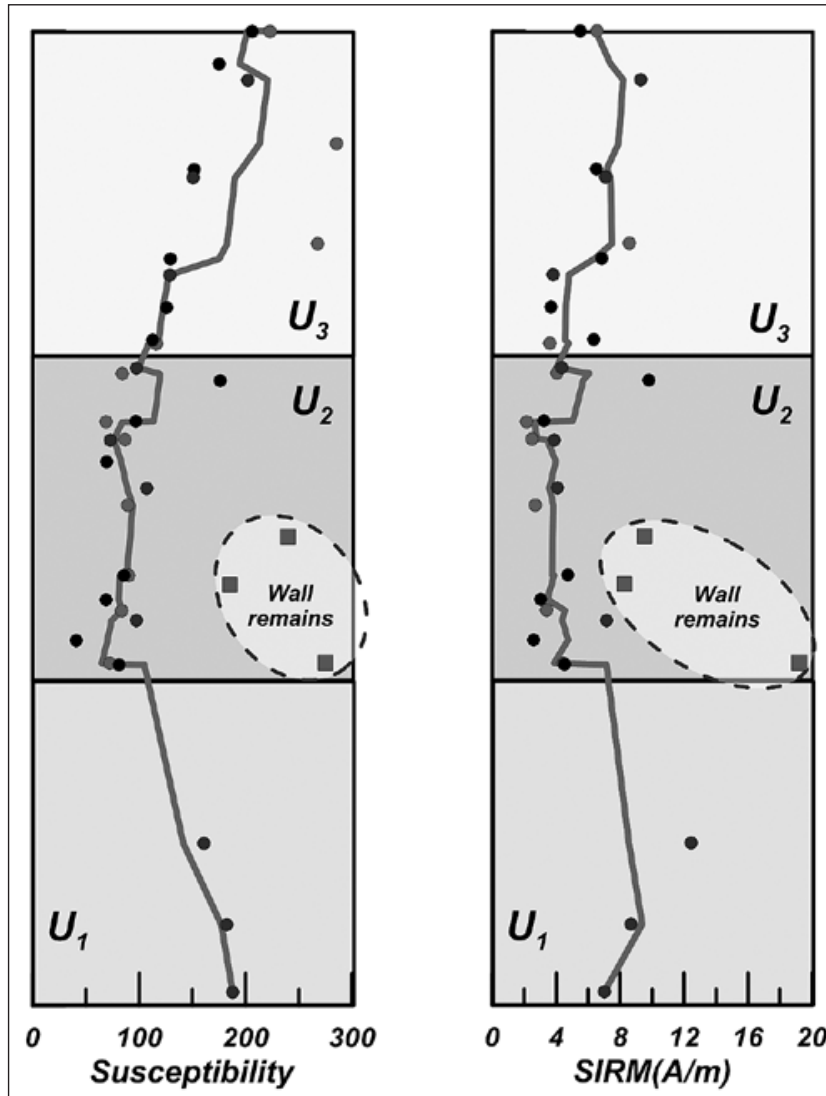

Fig. 6: Unified plot of magnetic susceptibility and SIRM for the three units $\left(U_{1}-U_{3}\right)$. Line corresponds to the moving average of all values.

\section{ACKNOWLEDGEMENTS}

The authors would like to express their gratitude to the archaeologists Miteletsis M. and Syros A. and to geologist J. Vlastaridis of the Ephorate of Paleoanthropology and Speleology of the Northern Greece for their help during the sampling, as well as for providing their evaluation of the archaeological data. Special thanks to Prof. Reidar
Lovlie and Prof. Stein Erik Lauritzen for their valuable conversations during the preparation of the manuscript. Dr. Kantiranis kindle performed the XRD analyses and is warmly thanked. The manuscript has been benefitted from the valuable comments of the reviewers Dr. Janez Turk and Dr. Nadja Zupan Hajna.

\section{REFERENCES}

Angelucci, D.E., 2003: Geoarchaeology and micromorphology of Abric de la Cativera (Catalonia, Spain).Catena 54, 573-601.

Bailey, G.N., Adam, E., Panagopoulou, E., Perles, C. \& K. Zachos, 1999: The Paleolithic archaeology of Greece and adjacent areas.- Proceedings of the ICOPAG Conference, British School at Athens, Athens, 1994.
Bar-Matthews, M., Ayalon, A., Kaufman, A. \& G.J. Wasserburg, 1999: The Eastern Mediterranean paleoclimate as a reflection of regional events: Soreq cave, Israel.- Earth and Planetary Science Letters 166, 85-95. 
Bar-Matthews, M. \& A. Ayalon, 2005: Evidence from speleothem for abrupt climatic changes during the Holocene and their impact on human settlements in the Eastern Mediterranean region: Dating methods and stable isotope systematic.- Zeitschrift fur Geomorphologie, Supplement band 137, 45-59.

Chatzopoulou, K., Vasileiadou, A., Koliadimou, K., Tsoukala, E., Rabeder, G. \& D. Nagel, 2001: Preliminary report on the Late Pleistocene small mammal fauna from Loutraki Bear-cave (Pella, Maced., Greece).Cadernos Lab. Xeolóxico de Laxe, 26: 485-495, Coruña, Spain.

Collcutt, S.N., 1979: Analysis of Quaternary cave sediments.- World Archaeology 10, 290-301.

Courty, M.A. \& J. Vallverdu, 2001: The Microstratigraphic Record of Abrupt Climate Changes in Cave Sediments of the Western Mediterranean.- Geoarchaeology: An International Journal 16, 467-500.

Dalan, R., 2008: A review of the role of magnetic susceptibility in archaeogeophysical studies in the USA: Recent developments and prospects.- Archaeological Prospection 15, 1-31.

Dearing, J.A., Dann, R., Hay, K., Lees, J., Loveland, P., Maher, B. \& K. O’Grady, 1996: Frequency-dependent susceptibility measurements of environmental materials. -Geophysical Journal International 124, 228-240.

Ellwood, B.B., Petruso, K.M., Harrold, F.B. \& M. Korkuti, 1996: Paleoclimate characterization and intra-site correlation using magnetic susceptibility measurements. and example from Konispol Cave, Albania.J. Field Archaeol., 23, 263-271.

Ellwood, B.B., Harrold, F.B., Benoist, S.L., Straus, L.G., Morales, M.G., Petruso, K., Bicho, N.F., Zilhao, J. $\&$ N. Soler, 2001: Paleoclimate and Intersite Correlations from Late Pleistocene/Holocene Cave Sites: Results from Southern Europe.- Geoarchaeology: An International Journal, 16, 433-463.

Ellwood, B.B., Harrold, F.B., Benoist, S.L., Thacker, P., Otte, M., Bonjean, D., Long, G.J., Shahin, A.M., Hermann, R.P. \& F. Grandjean, 2004: Magnetic susceptibility applied as an age-depth-climate relative dating technique using sediments from Scladina Cave, a Late Pleistocene cave site in Belgium.- Journal of Archaeological Science 31, 283-293.

Evans, M. \& F. Heller, 2003: Environmental Magnetism - Principles and Applications of Enviromagnetics. Academic Press, pp. 293.
Frisia, S., Borsato, A., Mcdermott, F., Spiro, B., Fairchild, I., Longinelli, A., Selmo, E., Pedrotti, A., Dalmeri, G., Lanzinger, M. \& K. van der Borg, 1998: Holocene climate fluctuations in the Alps as reconstructed from speleothems.- Preistoria Alpina 34, 111-118.

Gamble, C.S., 1986: The Paleolithic settlement of Europe. Cambridge University Press, Cambridge, pp. 471.

Hamlin, R.H.B., 2000: Environmental change and catastrophic flooding in the Voidomatis and Aoos Basins, Northwest Greece.- PhD Thesis, Leeds, University of Leeds, UK.

Karkanas, P., 1999: Lithostratigraphy and micromorphology of Theopetra cave deposits, Thessaly Greece: Some preliminary results.- In G.N. Bailey, E. Adam, E. Panagopoulou, C. Perle's \& K. Zachos (Eds.), The Palaeolithic archaeology of Greece and adjacent areas, pp. 240-251, British School at Athens Studies 3., British School at Athens, London.

Karkanas, P., 2001: Site formation processes in Theopetra Cave: A record of climate change during the late Pleistocene and early Holocene in site formation processes in Theopetra Cave.- Geoarchaeology: An International Journal 16, 373-399.

King, J. \& J.E.T. Channell, 1991: Sedimentary magnetism, environmental magnetism, and magnetostratigraphy.- In: U.S. National Report to International Union Geodesy and Geophysics. Rev. Geophys. Suppl., 29, 358-370.

Lewin, J., Macklin, M.G. \& J.C. Woodward, 1991: Late Quaternary fluvial sedimentation in the Voidomatis Basin, Epirus, northwest Greece.- Quaternary Research, 35, 103-115.

Papafilippou-Pennou, E., 2004: Dynamic evolution and recent exogenic processes of Strymon river network in Serres graben (North Greece).- PhD, Aristotle University of Thessaloniki, $212 \mathrm{pp}$. (in Greek with extended English abstract).

Pennos, Ch., Vaxevanopoulos, M., Syros, A., Miteletsis, M., Pechlivanidou, S. \& I. Vlastaridis, 2008: Genesis and development of caves in Katarraktes region Sidirokastro, Macedonia, Greece. A geoarchaeological approach. - 5th Symposium of the Hellenic Society of Archaeometry, 8-10 October, Thessaloniki, Greece. (in Greek)

Poulaki-Pantermali, E., Vaxevanopoulos, M., Koulidou, S. \& A. Syros, 2006: Dam Katarraktes in Sidirokastro.- Archaeological Work in Macedonia and Thrace, 18th Scientific Meeting, Thessaloniki, Greece, 63-71. (in Greek) 
Psilovikos, A., Vavliakis, E. \& L. Sotiriadis, 1981: Granite core stones and tors in the Vrontou mountains.- Arbeit Institut Geographie 8, Salzbourg, 63-78.

Psomiadis, D., Dotsika, E., Zisi, N., Pennos, Ch., Pechlivanidou, S., Albanakis, K., Syros, A. \& M. Vaxevanopoulos, 2009: Geoarchaeological study of Katarraktes cave system (Macedonia, Greece): isotopic evidence for environmental alterations.- Géomorphologie: relief, processus, environnement, 4, 229240.

Seferiades, M., 1983 : Dikili Tash: introduction à la Préhistoire de la Macédoine orientale.- Bulletin de correspondance hellénique 107, 635-677.

Sherratt, A.G., 1986: The Pottery of Phases IV and V: The Early Bronze Age.- In: Renfrew C., Gimbutas M. \& E.S. Elster (Eds.): Excavations at Sitagroi. A Prehistoric Village in Northeastern Greece. - Monumenta Archaeologica 13, University of California, Los Angeles, 429-476.

Šroubek, P., Diehl, J.F., Kadlec, J. \& K. Valoch, 1998: Preliminary study on the mineral magnetic properties of sediments from the Kulna Cave.- Studia Geophysica et Geodaetica 3, 301-312.

Šroubek, P., Diehl, J.F., Kadlec, J. \& K. Valoch, 2001: A Late Pleistocene paleoclimate record based on mineral magnetic properties of the entrance facies sediments of Kulna Cave, Czech Republic.- Geophys J. Int. 147, 247-262.

Šroubek, P., Diehl, J.F. \& J. Kadlec, 2007: Historical climatic record from flood sediments deposited in the interior of Spirálka Cave, Czech Republic.- Palaeogeography, Palaeoclimatology, Palaeoecology 251, 547-562.

Stober, J.C. \& R. Thompson, 1979: Magnetic remanence acquisition in Finnish lake sediments.- Geophysical Journal of the Royal Astronomical Society 57, 727-739.

Straus, L.G., Eriksen, B.V., Erlandson, J.M. \& D.R. Yesner, 1996: Humans at the end of the Ice Age: The archaeology of the Pleistocene-Holocene transition.- Plenum Press, New York, 365 pp.

Straus, L.G., Morales, M.G., Farrand, W.R. \& W.J. Hubbard, 2001: Sedimentological and stratigraphic observations in El Miron, a late quaternary cave site in the Cantabrian Cordillera, northern Spain.- Geoarchaeology: An International Journal 16, 603-630.
Syros A., Tsagkouli, C., Myteletsis, M. \& I. Vlastaridis, 2008: Cave in Katarraktes-Fragma site in Sidirokastro.- Archaeological Work in Macedonia and Thrace, 20th Scientific Meeting, 12 March, Thessaloniki, Greece. (in Greek)

Syros, A. \& M. Miteletsis, 2012: Cave in the site Katarraktes, Sidirokastro, Serres, Greece.- In The Neolithic and Bronze age Balkans, eds, in press.

Thompson, R. \& F. Oldfield, 1986: Environmental Magnetism. Allen and Unwin, pp. 227, London.

Toškan, B. 2009: Small terrestrial mammals (soricomorpha, chiroptera, rodentia) from the early holocene layers of Mala Triglavca (SW Slovenia).- Acta carsologica, 38, 117-133.

Turk, J. \& M. Turk, 2010: Paleotemperature record in late Pleistocene clastic sediments at Divje babe 1 cave (Slovenia).- Journal of Archaeological Science 37, 3269-3280.

Weymouth, J., 2003: Hopeton Geophysical Survey: The 2003 Season. Report submitted to the Midwest Archeological Center, National Park Service: Lincoln, NE.

Woodward, J.C. \& P. Goldberg, 2001: The Sedimentary Records in Mediterranean Rockshelters and Caves: Archives of Environmental Change.- Geoarchaeology: An International Journal 16, 327-354.

Woodward, J.C., Hamlin, R.H.B., Macklin, M.G., Karkanas, P. \& E. Kotjabopoulou, 2001: Quantitative sourcing of slackwater deposits at Boila rockshelter: A record of lateglacial flooding and paleolithic settlement in the Pindus Mountains, Northwest Greece.- Geoarchaeology: An International Journal 16, 501-536.

Zupan Hajna N., Mihevc A., Pruner P. \& P. Bosák 2010: Palaeomagnetic research on karst sediments in Slovenia.- International Journal of Speleology, 39, 2: 47-60. Bologna. 